\title{
Education for Development: Myth or Reality? The Kenyan Experience
}

\author{
John Koskey Chang'ach \& David Kipkasi Kessio \\ Moi University, Kenya
}

Accepted: April 13, 2012 Published: May 19, 2012

Doi:10.5296/ijld.v2i3.1819ＵRL: http://dx.doi.org/10.5296/ijld.v2i3.1819

\begin{abstract}
Education is seen as a powerful tool by which men and women are liberated from their natural state whether that described as ignorance, poverty, disease, selfishness, fear, corruption, injustice, enslavement, moral bankruptcy, or some other undesirable conditions and therefore freedom is the goal of education. Since attaining her political independence in 1963, Kenya has continued to invest heavily in education with the hope that this would help to transform the country into a modern progressive state. Kenya, fifty years after independence she is still bedeviled by corruption, bad governance, negative ethnicity and impunity. Although Kenyans have acquired literacy, academic knowledge and skills, education has not translated into the kind of thinking, mental attitudes and behaviour that is necessary for transforming society. This paper will explore the liberating and transforming power of education at the level of the individual and the society. It will then go on to demonstrate that only the right or intellectual learning at the expense of values and character education is responsible for our educational failure in Kenya.
\end{abstract}

\section{Introduction}

There exist conventional assumptions that education is the single most vital element in combating poverty, (UNICEF, 1993) and that an educated population contributes to the socio-economic development of society and well being of individuals within society (Fagerlind and Saha, 1983). Yet, emerging paradigms in development research reveal a contrary relationship between education and development. What kind of education? What development? This has led to a growing belief among educational planners, economists, employers, development workers, politicians and academicians that education has failed to effectively function as the critical tool of development and liberation it ought to be (World Bank, 1993).

No matter where one begins the discussion of the complex subject of development, one will gain only a partial view of its scope and depth. However, in Kenya's case, this paper 
examines education as a very revealing aspect of the nature and the magnitude of the development dilemmas and challenges. But more importantly the opportunities ahead of us, in this discussion therefore, the paper looks at the entire development process through the lens of the education enterprise.

The paper examines the approaches used in the education system for both policy planning and implementation, as well as methods used during the learning process. In order to get an overview of the cost-benefit status of the educational enterprise, the paper takes a snapshot analysis of the various forms of costs involved in pursuing and sustaining it, and the impact it has had on individuals, systems and institutions. By so doing, the paper intends to assess to what extent education has functioned as an effective tool of development, and how in certain aspects, it has tended to become part of the development problem itself, as the emerging post-modernist school of thought holds (Rodney, 1989).

This discussion, as Kabiru Kinyanjui once recommended, is an attempt at theorizing from reality rather than fitting the reality into existing paradigms (Himmelstrand et al., 1994). It represents what in this paper is viewed as a creative and realistic approach to development debate and practice and how they relate to the education system and its processes. The paper uses the reality of Kenya's escalating mass poverty, civil strife, social disintegration, wild unemployment of both the "educated" and "non-educated", widespread apathy, widening inequality gaps and moral degeneration, "impunity" among others, to show that despite the ever-growing private and public investment in education for over half a century, the development expected from it is still wanting.

In this case, the almost unquestioned hypothesis that formal education is a universal factor of development, has stayed uncontested for too long, even when data is there to show that the system basically produces disoriented school drop-outs and impractical graduates, who, more often than not, turn out to be social and economic misfits and a liability to already exhausted family and national resources. The high opportunity costs involved in the existing education investment are prohibitive enough to nullify the classical paradigms and hypothesis of education.

\section{The Model Role of Education}

Whatever perspective one uses to define it, and whichever form it takes, education seems to be universally recognized as a tool of personal improvement and social progress. In this discussion, the paper grapples with questions like:

- Is education wiping out poverty or the poor people themselves?

- Is education a response to emerging needs or to traditional ideologies?

- Is education in all forms and all situations a factor of development?

- Does education mean the same thing as schooling?

- What is the top priority on Kenya's education agenda?

- Who sets the agenda and who are the winners and losers? 
This paper could have an endless litany of such questions whose main object is to establish the relationship between Kenya's underdevelopment and the education system. To cut the litany short, the paper shall analyze statements which are made in most graduation ceremonies and the other, by a key figure to get the gist of the matter. One is by a repeat of words by most Chancellors and the other, Kofi Annan, former Secretary General of the United Nations.

During graduation ceremonies, graduands are normally addressed on life after college. This was no different during $25^{\text {th }}$ Congregation for the Conferment of Degrees and Award of Diplomas of Moi University held on $10^{\text {th }}$ Decemberr, 2010 by Professor Bethwell Allan Ogot, the Chancellor, who told the graduands "We have played our part. Go out and work. Your success is our success; your failure is yours alone".

At the core of this statement lies a leading attitude, an attitude which cements the very capital with which the edifice of poverty and underdevelopment is built. The Chancellor's statement embodies society's powerlessness over effective quality control mechanisms for holding educationists answerable for the nature of products they bring to job market. This prevents education from being a dynamic response to emerging needs and instead conserves it as a response to traditional paradigms and ideologies. It is a central player in Kenya's poverty drama. That is how the school has turned into "an agent of modernized poverty" (Illich, 1970).

That very statement unveils the complacency and arrogance with which schools have remained blind to the damage they have inflicted on society. The schools are not willing to listen to the changing needs of society so as to produce relevant manpower. Take for example the reaction of the universities after the call by Hon. William Ruto former Higher Education minister to the universities to scrap some university Arts courses and or modify some of them. The universities are only willing to produce graduands according to its own standards, standards which are, in most cases based on out-dated ideologies. If, by any chance the school graduates find something to do with them, well and good. If they don't too bad. Blame it on their "bad luck", nobody is to blame, not even the schools that have plundered their money and time and given to them wrong prescriptions.

How can society comfortably and safely contend that the school has nothing to do with the failure of its products, but at the same time say that the latter owe their success to the former? To say the least, this is the double standards by which schools have continued to falsely justify a conservative tradition despite changing societal needs. In this contradiction lies the deadly deception that schooling in its present form is an unquestionable factor of development.

Moreover, in the midst of these paradoxes Kenyans continue to hear the chorus of what seems to be a global consensus that education is the master key to development. From the political slogans of a local chief in the remotest village in Kenya, to the biggest volumes of UNICEF dogmas, this seems to be the incontestable position. However, the paper will pick out just a 
few points raised in the Geneva circles to show that education is not necessarily an automatic path to development. On the contrary, it can also function as a factor of underdevelopment.

Kofi Annan, former Secretary General of the UN, in his foreword to the 1999 UNICEF report entitled The State of the World's Children, wrote:

Education is a human right with immense power to transform. On its foundation rests the corner stone of freedom, democracy and sustainable human development (UNICEF, 1999).

This paper might naturally agree with this position, but it remains vulnerable to a vigilantly living question: What do I do when a human right turns into a threat to the existence of the very people it was meant to protect? Unfolding developments in the education sector show that even the best food can become poison if misused. In most part, Africa's education seems to have become a catalyst of underdevelopment due to bad approaches. It is a human right that has been abused.

Kofi Annan continues to emphasize that:

...the right to education (is an imperative necessitating) establishing schools as oases of respect and encouragement for children....it is giving us classrooms where principles of democracy are upheld and embraced (UNICEF, 1999).

On the opposite side of Annan's conviction lie some crucial questions which might give a clue as to why education has not necessarily served its due role in Kenya.

- Why must the classroom continue to be an oasis of respect? Is it not true therefore that respect is artificial and cannot apply in the real world?

- Why has this classroom respect failed to come out of the classroom, for in real life we don't live in classrooms? We live in villages, in communities, slums, workplaces, with all our differences politically, culturally, economically and in religion?

- Why is it that the perpetrators of anti-democracy behaviour (the police officers and politicians) are those who have served several years on the benches of the same classrooms that Annan refers to as the nursery bed of the principles of democracy? In Kenya it is not the "uneducated" peasants who start up ethnicity, grab public land and are involved with big time corruption cases. It is the "educated" elite.

- Does it not therefore, mean that the classroom knowledge and processes are divorced from contextual realities and are therefore distortive, disorienting and alienating?

- If millions of those of us who have gone through the classroom have failed to extend these oases of respect and encouragement to the wider society, is it not time to question the relevance of those oases, as well as the relevance and appropriateness of the classroom processes and products? 
Yet in the conclusion to his foreword, Annan says:

There is no instant solution to the violations of that right (right to education) but it begins with a simple proposition that on the eve of the $21^{\text {st }}$ century, there is no higher priority, no mission more important than that of Education For All (UNICEF, 1999).

The question still remains: "What education?" If he means the one that Kenyans know now, then Annan got his priorities mixed up, at least for Kenya. If the children who have passed through the school have been severely deformed, especially in regard to attitude, that they have been oriented to be perpetual dependents, is the priority to multiply the same menu so that many more can access it? Is it not more prudent to devote more resources to making the educational menu healthy first, however small it may be? What is better, to be underfed in the short-run with greater prospects for improved rations, or to be poisoned? Of reforms geared towards better and relevant quality, and those geared towards expansion, which ought to precede the other? Isn't the unfiltered obsession with Universal Primary Education as is set out in the Millennium Development Goals likely to breed Universal Pauperization Education? The dilemma is that complicated.

The motive in this interrogation is not to rubbish what Kofi Annan is saying, because he is presenting a position in which we all believe as a matter of principle. The discussion is focused on redefining these principles in the context of Kenya's contending problems and needs.

Official circles normally present illiteracy as one of the major hindrances to reduction in mass poverty and underdevelopment. In fact, the 1948 Universal Declaration of Human Rights elevated the status of education from being looked at as a people's need to a Right. Article 26 of the declaration provides that: "The right to Education shall be directed to the full development of the human personality and to strengthening of respect for human rights and fundamental freedoms".

The World Conference on Education for All held in Jomtien (Thailand) in 1990 re-emphasized the international consensus that:-

Education is the single-most vital element in combating poverty, empowering women, protecting children from hazardous and exploitative labour and sexual exploitation, promoting human rights and democracy, protecting the environment and influencing population growth.

In more emphatic terms the Conference further argued that:

Without an education, people cannot work productively, care for their health sustain their families or live culturally enriched lives. Illiteracy makes it difficult for them to interact in society in a spirit of understanding, peace, tolerance and gender equality among all people and groups. 
This kind of position that seeks to rightly rationalize heavy investment in education has characterized most of the poor countries over the second half of the $20^{\text {th }}$ century. Among development economists, education investment has been traditionally justified on the basis of two broad assumptions:

(a) That an educated population contributes to the socio-economic development of the society as

a whole, and

(b) That it contributes to the well being of individuals within society (Theodre, 1983).

Proceeding from the same premises, in 1960 two regional conferences on education in Africa and Asia set the ambitious target of Universal Primary Education by 1980. And over the following decades education has been a boom industry in these regions. In $196045 \%$ of primary age children and $21 \%$ of secondary age were in school in the less developed countries. But by 1970 the primary enrolment had shot up to $62 \%$ and that of secondary to $32 \%$ (Harrison, 1983).

\section{Meaning and Purpose of Education}

The concept of 'education' has been metaphorically likened to that of 'medicine' (Hirst and Peters, 1970). Hirst and Peters (1970) argue that just as in the practice of medicine the doctor is mainly concerned with 'Curing' people through a 'family of processes', educating people also suggests a family of processes whose principle unity is the development of desirable quality in them." Hence, for the two scholars, educational reasons are connected with the development of desirable qualities in people. Such a position has its origin in the 'classical' view of education based on Plato's rationalism.

Plato's "The Republic" is held in high esteem as a master-piece on educational philosophy. His definition of the term is drawn from the word's Latin etymology "educere", meaning "to draw out from" - to bring out what is latently there (Cooney et al, 1993). In his sense, Plato looks at the purpose of education as facilitation of one to develop the potentials and abilities that are already inherent. This is what, Aristotle normally represented with the analogy of "a midwife - helping to give birth to ideas which are already born in the soul of each and every one of us"

It is actually here that Plato finds a profound meeting point with Jean Jacque Rosseau's perception of education. Rosseau argues that the individual is born unique and endowed. But that due to bad education "society can turn the individual, with all the uniqueness and dignity befitting a true individual, into merely another member of the herd, where individuality becomes lost in the faceless crowd.

Rosseau's position rhymes well with Plato's philosophy when he (Plato) asserts that education "is not about putting information into empty heads, like sight into blind eyes" He contends 
that human beings innately posses understanding, though in inchoate, undeveloped form. And therefore, education's purpose is to draw out from the mind the understanding which is already therein. On the contrary educational methods in Kenya largely focus on pumping information into the assumed "empty heads" of students.

In The Republic, Plato presents the education process in a dramatic imagery of a people accustomed to living in a dark cave, at the month of which is the genesis of a whole new and strongly dazzling light. The environment of the cave represents a captivating ignorance, and once out of the wayfarer, again one goes through stages of "enlightenment". This marks the developmental process each individual will go through in true education. In this figurative language Plato is implying education to be the force of enlightenment or liberation from the imprisoning "environment". Plato's liberative role of education is also to be found in the twentieth century's Paulo Friere's school of thought which looks upon "the educational system as the means by which people become truly liberated" (Farrant, 1980).

Shiniki Suzuki, a Japanese educational philosopher born in 1898, sees education as a tool for nurturing (Suzuki, 1969). He contends that "any child has seeds of ability which can be nurtured as far as the capacity of the brain will allow" (Cooney et al, 1993).

Still Suzuki used the analogy of the plant seed to describe the purpose of education. If adults are considered as full-grown plants, then he refers to children as the seedlings. "Unless the seedlings are well cared for, beautiful flowers cannot be expected", he holds. He underpins the role of parents, especially during the pre-school age, in a child's educational process. And for him "the fate of the child is in the hands of his parents" In Suzuki's perspective, the foundation of education is to carefully raise children with the ability to be fine human beings without being hindered by their individual characteristics. And like other philosophers before him Suzuki held that the child does not become educated once and for all and all of sudden. Education is a life-long process and on-going.

\section{Current Educational Postulation}

The term 'education' is wrongly used when made synonymous with a schooling system. As such therefore, it has been intimately linked to those activities that take place in the institutions of learning like numeracy, literacy and formalized skills training or special literary, theoretical or scientific mastering.

Albert Ozigi offers one such a definition:

Education is the process of acquiring knowledge gained by experience or learning. The aim of education is not only to give skills to an individual for productive employment but to assist him in endeavours for scientific and artistic uplift and spiritual well being (Canham, 1984).

Whereas, by implication Ozigi definition is brought in the context of schooling, Onyang'o has definition which offers a broad perspective of the term: 
This process of increasing awareness about society, of analyzing its challenges and trying to find solutions, is what is referred to as Education in its broadest term.

Onyango's broad perspective of education offers an important insight into the kind of education that existed in Kenya, for example before the Missionaries introduced formal institutionalized learning, popularly known as schooling. Onyang'o explains:

Through this system the fisherman taught his son how to build canoes and to preserve fish. He also taught his son how to appease the gods of the sea and which fish could be eaten by women and which were a preserve of men. In the same way a mother taught her daughter how to preserve cassava and how to cut the baby's umbilical cord.

Still, Onyang'o offers another important insight into the negation that exists in both the indigenous type of education described above and the present formalized schooling. $\mathrm{He}$ contends that in both forms, there is a tendency to confuse certain processes of the whole and to substitute them for education itself. In the same context Onyang'o propounds education as a process that "brings self-improvement to acquire perceptive power and skill to live in the environment" Certainly, as used in this context; the environment represents all the aspects of life. Thus, the implication is that education must, to its best, focus on developing one's diverse faculties.

\section{Education and Development}

Ozigi definition of development is a classical representation of the interlocking nature of these concepts. It also demonstrates that it is practically impossible to sensibly talk about one without implicating the other. He asserts:

Development [is] a transformation within a society with increased awareness and perception of its immediate environment and the challenges presented therein. Aware of these challenges members of the society feel the urge to improve their conditions by analyzing the problems and the needs and taking steps to ameliorate these conditions and adopt innovations for the betterment of society (Canham, 1984).

The words 'awareness', 'analyzing' and 'innovations', as used in this definition have a direct or implied connotation of a process that brings information to bear on people's world outlook, and therefore influence their 'intellectual' undertakings (the way they philosophize) and how they respond to circumstances. In both traditional and "modern" society this process of transmitting such causative information is a function of the education system. It might be through oral tradition, apprenticeship or formal training or instruction in institutions (schools). The information imparted into a people is what determines their perceptions of themselves and their environment and consequently what they do and how they do it. Cater Woodson 
epitomized the influence of education (the information imparting system/process) on people's activities in the following words:

If you determine what a man shall think, you do not have to concern yourself about what he will do. If you make a man feel inferior you do not have to compel him to accept inferior status; for he will seek it himself. If you make a man feel he is justly an outcast, you do not have to order him to back-door; he will go without being told and if there is no back-door his very nature will demand one (NESCAA, 2000).

At the same time, however, the nature of the information-imparting system and of the means used in that system (technology), as well as that of the information itself, are all influenced, or actually determined by the level of a society's development (To use Gustavo's definition: the level to which people have reached in actualizing their potential). That is why this discussion contends that Kenya's educational system and rampant poverty and general underdevelopment in our midst, are closely related.

Page (2008) offers a deeper insight into this analysis. He argues education and development is a neutral one without a normative directional connotation or a defined unilateral causative relationship between the two concepts. His emphasis on the neutrality is because it "leaves open the possibility that education may have positive or negative effects on development objectives. This "neutrality" comes in the wake of the rejection of the two notions of 'Education for Development' and 'Development Education'. He argues that 'both phrases [seem] to have normative overtones in that they implied the search for prescriptive guidelines in the use of education for prescriptive purposes. In his perspective, to speak of 'Education for Development', begged the question about the possibility that education could, in given contexts, completely undermine development objectives.

In Plato's analogy of the 'cave of ignorance', which we alluded to earlier, he articulates his perception of education as a tool of social transformation. He assumes that once an individual, formerly in the cave, has gone through the enlightenment process (education), the enlightened individual feels the moral obligation to return to the setting of the cave to help the other captives to release themselves from the darkness of ignorance...the truly educated person responds to the duty of all human beings... we are social beings...we need each other even to be our selves (Cooney et al., 1993).

In this way, Plato, just like John Dewey, regards education not as just an end in itself but more importantly, as a means to an end the liberation of the masses. The chief difference between them is that Dewey avoids Plato's romantist philosophy of the nature and purpose of education. He amplified in the strongest expression that "ideas are valuable if and only if they make a real difference in our day-to-day life". But still this discussion contends that education in Kenya has not really played this "social liberation" function. 
Dewey has actually been labeled an apostle of pragmatism. This is because for him education is of any value only in as far as it enables the individual to contribute to society's growth. He in fact shares with Plato the conviction that education and social structures are interrelated and must be treated simultaneously. And the theme of education as a factor of empowering individuals to shape and adapt to their environment cuts across his discourse.

Robert M. Hutchins was opposed to the reformist philosophy which represented the doctrine of adaptation or life adjustment, whose object was to fit the student into his physical, social, political, economic and intellectual environment with a minimum discomfort to society (Husen, 1979).

According to Hutchin, this "misconceived" pragmatism with a strong emphasis on vocational training or career education is "poor mechanics without education". He reiterates that this doctrine of adjustment to the demands of the environment easily leads to a curriculum of disconnected and "dead facts". Hutchin sees the worst part of life adjustment education in the sense that it overlooks the fact that "our mission here on earth is to change our environment, not to adjust ourselves to it".

In the context of escalating poverty in Kenya, educationalists and policy makers are continually caught up in the conflict between Hutchin's development of the individual (humanistic) and satisfying manpower needs for society, as the overriding aim of education (Hirst and Peters, 1970). The principal aim of education is increasingly looked at in view of its ability to solve social problems. And of course this cannot go without the risk of contradictions, even self-contradictions, both intended and unintended. Will the vocationalization of education for example, solve the current educational dilemma?

For example, while on the one hand the United Nations has expressed education as a human right with the basic purpose of "full development of the human personality" (United Nations, Universal Declaration of Human Rights Article 26) on the other hand, the same institution has had to shift emphasis to looking at education from a functionalistic perspective as a tool for poverty reduction (UNICEF, 1999).

A score of scholars and practitioners have reflected this UN paradigm through scholarly writing and policy measures, banking on the assumption that:

Education is the single-most element in combating poverty, empowering women, protecting children from hazardous exploitative labour and sexual exploitation, promoting human rights and democracy, protecting the environment and influencing population growth.

In fact the tone in which this position is expressed has tended to take a more emphatic direction by arguing that:

Without education, people cannot work productively, care for their health, sustain and protect themselves and their families or live culturally enriched 
lives. Illiteracy makes it difficult for them to interact in society in a spirit of understanding, peace, tolerance and gender equality among all people and groups.

Paul Harrison has consolidated this normative assumption by contending that education is not only the key to personal enrichment. In the Third World context, it should be the central mechanism by which entire villages and urban communities learn to develop themselves, their productive potential, and their resources (Harrison, 1987).

Schultz Theodre's (1983) school of thought with its theories of modernization and human capital has dominated the theoretical framework used in policy formulation and in directing the practice of education in most part of Africa.

In one of the studies that first examined the modernization theory, David McClelland, in his book, The Achieving Society, argues that at the core of the theory is a personality characteristic, which he called 'the achievement motive'. He explains that this motive is acquired through socialization which makes society open to economic and technological advancement. To McClelland education is the process responsible for creating and cultivating this achievement motive.

In the same line of argument, Alex Inkeles coined the notion of the need for achievement as a psychological trait, and went further to formulate a set of attitude questions known as the "modernity scale". He used this scale to measure the extent to which members of a given society hold what he considered to be modern values. Both Inkeles and McClelland look at education as the principal instrument for instilling the achievement motive and facilitating modern values.

Even in the midst of a strong wave of an emerging post-modernist paradigm of education, the optimism that education is the most important tool of development has kept outstanding. In 1999, James D. Wolfensohn, President of the World Bank, reaffirmed thus:

All agree that the single most important key to development and to poverty alleviation is education. This must start with universal primary education for girls and boys equally, as well as an open and competitive system of secondary and tertiary education (World Bank, 1999).

In a similar fashion, the World Bank still asserts that education affects how well individuals, communities and nations fare. It helps improve living standards and enhance the quality of life and can provide essential opportunities for all. And as a way of mapping out new strategies for the twenty-first century, the Bank looks at education as being central to the development agenda which is focused on "fighting poverty and improving quality of life".

\section{Education and Poverty}


Because education has had such a long established stereotyped position as an all-through positive thing, it has rarely been pointed at as a possible direct cause of the very poverty it is assumed to cure. Scholars and policy makers too, have understandably internalized a prejudiced popular belief.

But if one were to look at education in its comprehensive sense, as the socialization process that influences what people think, what they know, what they do, and how they do whatever they do, then it becomes unquestionably logical to deduce that, it is education that is answerable for people's condition of life.

Nevertheless, a score of scholars on education or poverty have coined analyses which, when critically analyzed come to the same premises. Racheal Heathey has noted that education systems in most African countries either cater for the children of existing elite, or they simply prepare a tiny number of the poor to enter the elite. Heathey argues that this happens because in most Third World countries the rural poor haven't yet won the power to force the educational system to respond to their needs (Heathey, 1979). Perhaps what such studies, as Heathey's, do not put bluntly is that, it is actually the education process (formal, informal and non-formal) which ought to empower people to influence decisions that affect them. If the education they have got in the first place has not empowered them to that effect, they might as well never "win" that 'power to force the educational system to respond to their needs' as Heathey advocates. Education is actually the starting point and what happens in society reflects the nature of the education system.

In their analysis of poverty, following global consultations with the poor, the World Bank poverty group came up with a model that explains the causes of poverty and the poor people's perception of "poverty", which in this study they refer to as "ill-being".

The group refers to development as "a good change - from 'ill-being' to 'wellbeing'. In this case, 'development' also implies a poverty-free condition.

Just like Heathey, the World Bank group identified 'powerlessness' as one of the five factors that bring about the 'ill-being'. The other factors are bad social relations, material lack/poverty, physical weakness and insecurity.

On the side of wellbeing, which connotes a poverty-free situation, the respective negative factors identified in 'ill-being' are transformed into positive attributes like Freedom of choice and Action; Good Social Relations; Enough for a Good Life; Physical Wellbeing and Security. But what the group does not seem to bring out openly is that the education processes is actually what determines whether people get empowered or remain powerless or even acquire a feeling of powerlessness. For poverty is basically a disease of the mind.

This observation fits in with the popular saying that "you are what you think and you think according to what you know, therefore, you are what you know". What people know and 
what they think is a function of education: formal, informal and non-formal. Education is the interactive process that shapes attitudes, values, behaviours, perceptions, skills and abilities. These in turn are the determinants of how people relate to each other, how they harness their environment to satisfy their material needs, how they cater for their physical development, how they feel about themselves and others (security) and how their socio-political institutions are. If these aspects of society have gone wrong as to bring about a situation of ill-being, it is just logical that the education system must be held answerable.

Page associates the folly of education in Africa with the root of poverty in the continent. He insists that education in Africa has been decisively anti-people. He refers to education as an enslaving process that perpetuates oppression and exploitation, and advocates for a relevant education that is poor-centered (which) can, without doubt, be a weapon against material poverty and mental or ideological bankruptcy (Carabine and O'Reilly, 1998).

Seemingly, Mataze's position is inspired by the observations of Roberto Gonzalez, minister of Foreign Affairs of the Republic of Cuba, who, talking about the existing education system in most developing countries, said:

It has produced civil servants who do not serve civil society but serve their own needs first; Politicians who speak but say nothing; voters who vote but do not elect, a media which misinforms; schools where they teach how to ignore; members of the judiciary who sentence victims and take bribes; a military that is always at war with the citizens it is meant to protect; a police force which cannot fight crime because it is busy committing crime; socialized bankruptcies and privatized profits; money which happens to be freer than people and people who serve things (Carabine and O’Reilly, 1998).

Gonzalez's observation places education at the core of the World Bank's poverty group's webs of 'ill-being' and 'wellbeing'. And from this perspective, the two webs and their underlying dynamics cannot be understood without considering education as the key socialization process that fundamentally influences those dynamics.

\section{Conclusion}

Critical and creative skills, strategies and attitudes ought to be integrated in the curriculum at all levels of education in Kenya. This could engender critical, creative, liberative and self-reliant citizens for development and self-determination. To overcome the problem of examination centred education, where schools compete for national ranking, Nyerere's idea that education should be cooperative endeavour that enables learners be creators and not creatures should be recommended. Education for liberation should equip learners with skills, knowledge, ideas, attitudes and values that promote self-reliance and respect while cooperating with others.

The analogy of education as a factory to process incoming behavior denigrates human dignity of learners into commodities exchangeable for money. This in effect borders on analogy of 
slavery and compromises human irreducible value. Whereas, education today is teacher-centred and learners are passive recipients of knowledge, Nyerere's idea that education should be learner-centred pedagogy, should be emphasized. The learners should be active participants by thinking, deciding, doing, discovering, experimenting and exploring.

According to Plato, education should enable learners to transcend and ascend their limitations through critical and creative consciousness. This involves problem-solving skills, aptitudes and techniques transferable in real life situations. He emphasizes on dialogical pedagogy where the teacher is a mid-wife of knowledge from learners' mind. The classroom is therefore, transformed from monologue of teacher to a community of inquirers with a culture of respect for all. Both Nyerere and Plato avail to us the lesson that education should liberate learners from restrictive mental habits, attitudes and conventions that imprison human potential for growth and development.

\section{References}

Abidi Syed A. H., (1991). Education for Development, (ed), Kampala: Foundation for African Development.

Aronowitz Stanely and Henry A. Giroux, (1985). Education under Siege, London: Routeledge and Kegan Paul.

Bigsten Arne and Steve Kayizzi-Mugerwa, (1998). Crisis, Adjustment and Growth in Uganda, New York: Macmillan Press Ltd.

Canham P. and Ozigi, A.(1984). An Introduction to the Foundations of Education. London: Macmillan Publishers.

Cooney William, Charles Cross and Barry Trunk, (1993). From Plato to Piaget 2 Boston: University Press of America.

Cosin Ben and Margaret Hales, (eds), (1983). Educational Policy and Society: Theoretical Perspectives, London: Routledge and Kegan Paul.

Day Barbara, (1983). Early Childhood Education, $2^{\text {nd }}$ ed., London: Macmillan Publishers.

De Bono Edward, (1992). Serious Creativity 2 New York: Harper Collins.

Deidre Carabine and Martin O'Reilly, (eds), (1998). The Challenges of Eradicating Poverty in the World: An African Response, Kampala: Uganda Martyrs University Press.

Donna H. Kerr, (1976). Educational Policy, Analysis Structure and Justification, New York: David Mckay Company, Inc. 
Farrant J. S., (1980). Principles and Practice of Education, Essex: Longman Group, UK Ltd.

Faure Edga, (1972). Learning to Be: The World of Education Today and Tomorrow, London: UNESCO Paris.

Fisher J. Robert, (1972). Learning How to Learn, New York, Harcout Brace Jonanovich Inc.

Forojjola S. B., (1993) Education Planning for Development, London: The Macmillan Press Ltd.

Fullan Micheal, (1982). The Meaning of Educational Reforms, New York, Teachers College Press.

Galan J. Saylor and William M. Alexander, (1974). Planning Curriculum for Schools, New York: Holt, Rinehard and Winston, Inc.

Goodman Paul, (1962). Compulsory Mis-education and the Community of Scholars 2 Toronto: Random House of Canada Ltd

Gribble David, (1998). Real Education: Varieties of Freedom, Bristol: Libertarian Education.

Greer Mary and Bonnie Rubinstein,(1972). Will the Real Teacher Please Stand Up? California: Goodyear Publishing Co. Inc.

Harrison Paul, (1987). Inside the Third World, London: Penguin Books.

Heathey Heathey, (1979). Poverty and Power, London: Zed Press, 1979.

Hirst P. H. and R. S. Peters, (1970). The Logic of Education, London: Routeledge.

Illich Ivan, (1970). Deschooling Society, New York: Harper and Row.

Ingermar Fagerlind and Lawrence J. Saha, (1983). Education and National Development: A Comparative Approach. New York: Pergaman Press Inc.

Lu Kost Mary, (1972). Success or Failure Begins in the Early School Years, Illinois: Charles C. Thomas.

Mouly George, (1968). Psychology for Effective Teaching, $2^{\text {nd }}$ ed., London: Holt Rinehart and Winston Inc. 
Page J. and Dolfin S. (eds),(2008). Africa at a Turning Point: Growth, Aid and External Shocks. Washington D.C.: The World Bank.

Peters J. Herman and James C. Hansen,(1977). Vocational Guidance and Career Development $3_{2}^{\text {rd }}$ Edition New York: Macmillan.

Pfeiffer John, (1968). New Look at Education: Systems Analysis in Our Schools and Colleges, New York: The Odyssey Press.

Psacharopoulos George and Mareen Woodhall, (1985). Education for Development, London: Oxford University Press.

Rosalind Charles Worth, Understanding Child Development, $2^{\text {nd }}$ ed., New York: Delmar Publishers Inc. 1987.

Sachs Wolfgang, (1992). The Development Dictionary, Johannesburg: Witwaterstrand University Press.

Shiniki Suzuki, (1969). Ability Development from Age Zero, Athens, Ohio: Ability Development.

Todaro Michael, (1985). Economic Development in the Third World, $3^{\text {rd }}$ ed., New York: Longman Inc.

Torsten Husen, (1979). The School in Question, Oxford: Oxford University Press.

Ulf Himmelstrand et al, (eds), (1994). African Perspectives on Development, Kampala: Fountain Publishers.

UNICEF, (1999). State of the World's Children Report, New York: UNICEF.

USA Government: (1972). Schools, People and Money: The Need for Education Reforms, President's Commission on School Finance Final Report.

Walter Rodney, (1989). How Europe Underdeveloped Africa, Nairobi: Heinemann Kenya.

World Bank, (1993). Education Sector Strategy, Washington: World Bank.

World Bank, (1999). Education Sector Strategy, Washington: World Bank. 